\title{
Ecological condition of water bodies of the south-west of Belarus in spring 2020
}

\author{
Larysa Kirichenko ${ }^{1, *}$, Aliaksandr Volchak $^{1}$, and Anna Golovach $^{1}$ \\ ${ }^{1}$ Brest State Technical University, Faculty of Engineering systems and Ecology, Maskouskaya str. \\ 267, 224017, Brest, Republic of Belarus
}

\begin{abstract}
In this work, hydrochemical and hydromorphological characteristics of urban reservoirs of southwestern Belarus in the spring of 2020 were investigated. Hydromorphological characteristics of reservoirs were determined by field methods and GIS mapping methods. Hydrochemical assessment of water quality of reservoirs in the spring period was carried out according to 15 indicators. Multivariate statistical methods were used to analyze surface water quality. Based on the analysis of hydrochemical and hydromorphological indicators, an assessment of the ecological state of the reservoirs of the urboterritories of southwestern Belarus in the spring period of 2020 was given. During the study, patterns of distribution of morphometric characteristics of the reservoirs within the studied territory were established. The analysis of hydrochemical characteristics showed that the water quality of urban reservoirs depends on the types of anthropogenic effects.
\end{abstract}

Keywords: urboterritory, water morphometry, water pollution level

\section{Introduction}

The development of urbanization usually negatively affects the ecological condition of the reservoirs located within the city, which depends on a set of factors, the most important of which is anthropogenic impact. Anthropogenic impact is expressed in the origin of the reservoir, changing its hydromorphological characteristics, the type and sources of pollutants entering the reservoirs of cities, in the degree of recreational load, in unauthorized water intake and waste water discharge, etc. This makes it increasingly difficult to determine the nature of the ecological status of the reservoir.

According to the classification of reservoirs according to the size of their water surface proposed by P.V. Ivanov, very small and small reservoirs (about 90\%) with a maximum depth of up to $5 \mathrm{~m}$ predominate among the reservoirs of Belarus [1]. Most of them are of anthropogenic or natural-anthropogenic origin. These bodies of water are not included in the State network for monitoring the ecological state of water bodies in Belarus, there are no characteristics of their hydromorphological parameters and ecological state, which does not allow to give a legal assessment of the negative impact on urbanized bodies of

\footnotetext{
* Corresponding author: lakobrinetch@mail.ru
} 
water [2]. In this regard, the study of the ecological state of urban reservoirs is especially relevant.

Modern climate change has disrupted the hydrological regime not only of rivers, but also of water bodies, including urban ones $[3,4]$. This is especially evident in the southwest of Belarus, a vivid confirmation of which is clearly shown by the spring of 2020 characterized by abnormal hydrological conditions: the absence of ice and spring flood on water bodies occurred due to abnormally high average monthly air temperatures and the absence of snow cover in winter. The developed weather conditions affected the ecological state of water bodies. During this period, the greatest transformation of the hydrological regime of water bodies takes place [4-6]. Therefore, the study of the ecological status of urban reservoirs during this period is of particular interest.

The purpose of this work is to study the ecological, hydrochemical and hydromorphological state of the reservoirs of the urbanized territories of southwestern Belarus in the spring in modern conditions.

During the study, the following tasks were solved:

1. Hydromorphological indicators of urboterritory reservoirs have been studied;

2. The assessment of hydrochemical parameters of water quality of urboterritory reservoirs in spring period is given;

3. The state of the investigated reservoirs in the spring period and their main environmental problems are determined.

\section{Methods}

The object of the study is typical reservoirs of urboterritories of southwestern Belarus. As a result, urban reservoirs were selected, where a representative sample is possible: Kobrin, Zhabinka, Malorita, Brest. All of them are characterized by flat catchments, natural-anthropogenic origin, nutrition due to groundwater and drainage reclamation canals.

When planning selection points, urban reservoirs are divided into four groups depending on the nature of anthropogenic impact: a) reservoirs in the area of private residential development (characterized by relatively low population density within the city limits); b) water bodies of the park area with an expressed recreational load; c) quarry reservoirs and d) reservoirs exposed to the expressed technogenic effects.

Hydromorphological characteristics of reservoirs were determined by field methods and GIS mapping methods according to the following morphometric parameters: maximum length $(L)$, maximum width $(B)$, water mirror area $(A)$, bankline length $\left(L_{l}\right)$. Based on these data, the bankline elongation indicator $\left(L^{*}=\frac{L}{B}\right)$ and the degree of bankline development $\left(S=\frac{L_{l}}{2 \pi \sqrt{\frac{A}{\pi}}}\right)$ were calculated [7-10].

Water sampling, preservation and transportation to determine hydrochemical indicators were carried out in accordance with the register of methods of chemical analysis of surface and wastewater of the Republic of Belarus. Water samples were taken from the nearsurface part of the reservoir from a depth of $0,3-0,5 \mathrm{~m}$. The samples were transported to the laboratory and stored in a refrigerator at $4^{\circ} \mathrm{C}$ for 24 hours. Water samples were analyzed within 24 hours after sampling. Water analysis by hydrochemical indicators was carried out by standard methods (Table 1).

The assessment of the environmental and hydrochemical status of urban reservoirs was carried out in accordance with the regulatory documents in force in Belarus [11-15]. 
Table 1. Water quality monitoring methods.

\begin{tabular}{|c|c|c|c|c|}
\hline Parameters & & Unit & Analytical method & $\begin{array}{c}\text { Minimum } \\
\text { detection limit }\end{array}$ \\
\hline $\mathrm{pH}$ & & - & potentiometric method & 0,01 \\
\hline Hardness total & $\mathrm{m}^{3}$ & $\mathrm{mmol} / \mathrm{d}$ & titrimetric method & 0,1 \\
\hline $\mathrm{Na}^{+}, \mathrm{Ca}^{2+}, \mathrm{Mg}^{2+}$ & & $\mathrm{mg} / \mathrm{dm}^{3}$ & drip electrophoresis method & 0,5 \\
\hline $\mathrm{Cl}^{-}, \mathrm{SO}_{4}^{2-}$ & & $\mathrm{mg} / \mathrm{dm}^{3}$ & drip electrophoresis method & 0,5 \\
\hline $\mathrm{CO}_{3}^{2-}, \mathrm{HCO}_{3}^{-}$ & & $\mathrm{mg} / \mathrm{dm}^{3}$ & acid-base titration method & 0,01 \\
\hline $\mathrm{PO}_{4}^{3-}$ & & $\mathrm{mg} / \mathrm{dm}^{3}$ & $\begin{array}{l}\text { spectrophotometric method with } \\
\text { ammonium molybdate }\end{array}$ & 0,005 \\
\hline $\begin{array}{l}\text { Chemical oxygen } \\
\text { demand } \\
\text { COD }\end{array}$ & $\mathrm{m}^{3}$ & $\mathrm{mgO}_{2} / \mathrm{d}$ & dichromatic method & 4 \\
\hline Dissolved oxygen DO & $\mathrm{m}^{3}$ & $\mathrm{mgO}_{2} / \mathrm{d}$ & slack method, iodometric titration & 1 \\
\hline $\begin{array}{l}\text { Biochemical oxygen } \\
\text { demand } \quad \mathrm{BOD}_{5}\end{array}$ & $\mathrm{~m}^{3}$ & $\mathrm{mgO}_{2} / \mathrm{d}$ & slack method, iodometric titration & 1 \\
\hline Iron total $\mathrm{Fe}_{(\text {total })}$ & & $\mathrm{mg} / \mathrm{dm}^{3}$ & $\begin{array}{l}\text { spectrophotometry with } \\
\text { sulfosalicylic acid }\end{array}$ & 0,1 \\
\hline Total mineralization & & $\mathrm{mg} / \mathrm{dm}^{3}$ & design method & - \\
\hline
\end{tabular}

\section{Results and discussion}

Morphometric characteristics of the investigated reservoirs of southwestern Belarus are shown in Table 2. On the basis of these indicators, the typification of urban reservoirs of southwestern Belarus was carried out and characteristic features of urbanized reservoirs were identified.

According to the accepted classification, the investigated reservoirs belong to very small $43 \%$ (area $\left.0,01-0,1 \mathrm{~km}^{2}\right)$, small $28,5 \%\left(0,1-1,0 \mathrm{~km}^{2}\right)$ reservoirs and to reservoirs with an area of water mirror $<0,01 \mathrm{~km}^{2}$ that were not included in the classification $28,5 \%$. These bodies of water are not included in the national monitoring system of water bodies, since their water surface area is less than $1 \mathrm{~km}^{2}$ [16]. However, based on the data obtained, 2/3 of the urban reservoirs are very small and water bodies with an area of up to $0,01 \mathrm{~km}^{2}$.

As a result of statistical data processing, based on the bankline elongation indicator $L^{*}$, the typification of urban reservoirs by type of pits is established:

a) bodies of water close to the oval shape $\left(L^{*}=3-5\right)-1$;

b) water bodies close to the rounded shape $\left(L^{*}=1,5-3,0\right)-2$;

c) rounded water bodies $(\mathrm{L} *=1-1,5)-9$;

d) water bodies close to square shape -1 (Vychulki pond).

The distribution of reservoirs according to the degree of development of the bankline (minimum value $\mathrm{S}=1,0$ - characterizes an absolutely round lake) in the western part of the Polesskaya lowland indicates that lakes with a small bankline rugged (slightly cut, S not more than 1,5) prevail in the studied territory. These are rounded reservoirs with a smooth bankline, characterized by the predominance of residual and technogenic-disturbed basins developed within the reclamation drained swampy Polesskaya lowland.

Thus, rounded water bodies prevail within the city. However, the main criterion for forming the shape of the urban reservoir is the degree of change (straightening, strengthening by embankments) of the bankline. It was established that for urban reservoirs 
the change in the bankline is significant ( $>5 \%)$, the bankline is straightened in almost all reservoirs, the banks of park reservoirs are strengthened by embankments.

Table 2. Hydromorphological parameters of some urban water bodies of southwestern Belarus.

\begin{tabular}{|c|c|c|c|c|c|c|c|}
\hline Pond & Origin & $\begin{array}{l}\text { Square } \\
A, \mathrm{~km}^{2}\end{array}$ & $\begin{array}{l}\max \\
\text { length } \\
B, \mathrm{~km}\end{array}$ & $\begin{array}{l}\max \\
\text { width } \\
L, \mathrm{~km}\end{array}$ & $\begin{array}{l}\text { bankline } \\
\text { length } \\
L_{l}, \mathrm{~km}\end{array}$ & $\begin{array}{l}\text { Degree of } \\
\text { bankline } \\
\text { development } \\
\qquad L^{*}\end{array}$ & $\begin{array}{l}\text { Elongation } \\
\text { factor } \\
\qquad S\end{array}$ \\
\hline \multicolumn{8}{|c|}{ town of Kobrin } \\
\hline $\begin{array}{l}\text { pond } \\
\text { Polesskaya St. }\end{array}$ & $\begin{array}{l}\text { Nature- } \\
\text { anthropogenic }\end{array}$ & 0,004 & 0,084 & 0,024 & 0,290 & 3,50 & 1,29 \\
\hline Park pond & $\begin{array}{l}\text { Nature- } \\
\text { anthropogenic }\end{array}$ & 0,02 & 0,200 & 0,102 & 1,545 & 1,96 & 3,08 \\
\hline \multicolumn{8}{|c|}{ town of Zhabinka } \\
\hline $\begin{array}{l}\text { Mukhina } \\
\text { Yama pond }\end{array}$ & $\begin{array}{l}\text { Nature- } \\
\text { anthropogenic }\end{array}$ & 0,002 & 0,064 & 0,039 & 0,250 & 1,64 & 1,58 \\
\hline $\begin{array}{l}\text { Vizzhar } \\
\text { reservoir }\end{array}$ & $\begin{array}{l}\text { Nature- } \\
\text { anthropogenic }\end{array}$ & 0,238 & 0,711 & 0,560 & 0,936 & 1,27 & 0,54 \\
\hline \multicolumn{8}{|c|}{ town of Malorita } \\
\hline $\begin{array}{l}\text { quarry } \\
\text { Dzerzhinskaya } \\
\text { St. }\end{array}$ & $\begin{array}{l}\text { Nature- } \\
\text { anthropogenic }\end{array}$ & 0,007 & 0,144 & 0,060 & 0,370 & 2,4 & 1,25 \\
\hline Park pond & $\begin{array}{l}\text { Nature- } \\
\text { anthropogenic }\end{array}$ & 0,016 & 0,170 & 0,123 & 0,512 & 1,38 & 1,14 \\
\hline Lake Military & $\begin{array}{l}\text { Nature- } \\
\text { anthropogenic }\end{array}$ & 0,093 & 0,452 & 0,302 & 1,180 & 1,50 & 1,09 \\
\hline $\begin{array}{l}\text { Peat-swamp } \\
\text { pond }\end{array}$ & $\begin{array}{l}\text { Nature- } \\
\text { anthropogenic }\end{array}$ & 0,286 & 0,784 & 0,493 & 2,45 & 1,59 & 1,29 \\
\hline \multicolumn{8}{|c|}{ town of Brest } \\
\hline $\begin{array}{l}\text { pond } \\
\text { Vasnetsov St. }\end{array}$ & $\begin{array}{l}\text { Nature- } \\
\text { anthropogenic }\end{array}$ & 0,012 & 0,156 & 0,090 & 0,44 & 1,73 & 1,24 \\
\hline $\begin{array}{l}\text { quarry } \\
\text { Kirpichnaya St. }\end{array}$ & $\begin{array}{l}\text { Nature- } \\
\text { anthropogenic }\end{array}$ & 0,060 & 0,535 & 0,238 & 1,66 & 2,25 & 1,91 \\
\hline $\begin{array}{l}\text { quarry } \\
\text { Gershonsky }\end{array}$ & $\begin{array}{l}\text { Nature- } \\
\text { anthropogenic }\end{array}$ & 0,201 & 0,692 & 0,319 & 1,86 & 3,72 & 1,17 \\
\hline Zerkalka pond & $\begin{array}{l}\text { Nature- } \\
\text { anthropogenic }\end{array}$ & 0,046 & 0,286 & 0,201 & 0,812 & 1,42 & 1,07 \\
\hline $\begin{array}{l}\text { Vychulki } \\
\text { pond }\end{array}$ & $\begin{array}{l}\text { Nature- } \\
\text { anthropogenic }\end{array}$ & 0,234 & 0,706 & 0,602 & 2,120 & 1,17 & 2,24 \\
\hline $\begin{array}{l}\text { Lower pond } \\
\text { May } 1^{\text {st }} \text { park }\end{array}$ & $\begin{array}{l}\text { Nature- } \\
\text { anthropogenic }\end{array}$ & 0,003 & 0,080 & 0,053 & 0,222 & 1,51 & 1,14 \\
\hline
\end{tabular}

In natural conditions, water bodies of the region of southwestern Belarus are characterized in composition as calcium-sodium hydrocarbonate [5]. Based on the studies conducted, it was found that in the reservoirs of areas of private development of urboterrritories of southwestern Belarus there is a slight heterogeneity in the ionic composition of water, they can be described as calcium-magnesium hydrogen carbonatechloride (Figure 1a). In the pond on Polesskaya street in Kobrin $\mathrm{Ca}^{2+} \mathrm{Na}^{+}$and $\mathrm{HCO}_{3}{ }^{-}$ions dominate. In the pond of Mukhina Yama in the town of Zhabinka the water is calcium hydrocarbonate-chloride. In a quarry on Dzerzhinskaya street in Malorita the water is sodium hydrogen carbonate-chloride. In the water of the pond on Vasnetsov street and pond Zerkalka in Brest established the predominance of $\mathrm{Mg}^{2+}$ and $\mathrm{HCO}_{3}{ }^{-}$ions. The increased content of $\mathrm{Mg}^{2+}$ and $\mathrm{Cl}^{-}$in the water of reservoirs is associated with the ingress of unorganized stormwater runoff from household areas and roads [17-20]. 


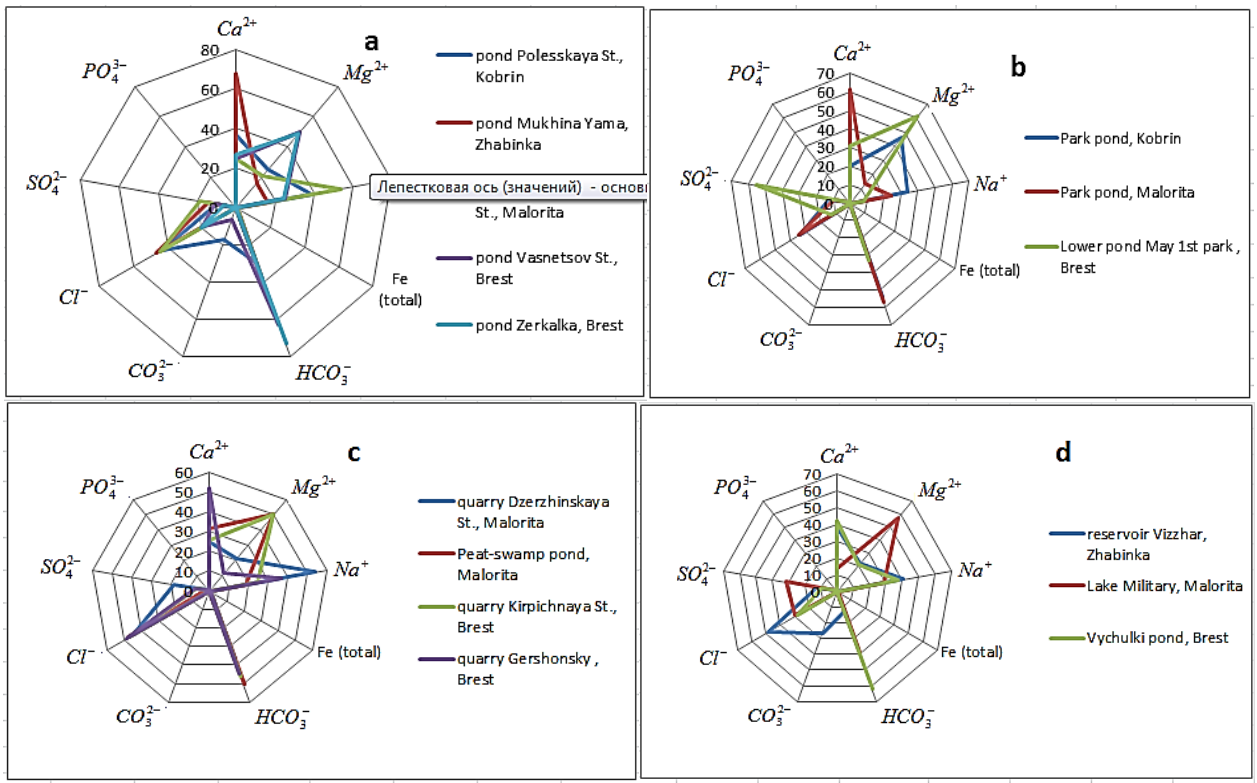

Fig. 1. The composition of water of the urban reservoirs in the spring period of 2020: a) of private residential development; b) in park ponds; c) quarry reservoirs and d) reservoirs with expressed anthropogenic influence.

In the park ponds of Kobrin and Brest, increased concentrations of $\mathrm{Mg}^{2+}, \mathrm{SO}_{4}{ }^{2-}$ and $\mathrm{Cl}^{-}$ ions (Figure 1b) are connected with the ingress of perennial unorganized storm drains from the adjacent green territory of the parks (annual fertilization of vegetation) and high recreational load (in these parks there is an annual high attendance of people). In the Park pond of Malorita, the least anthropogenic impact was established, the water in the reservoir belongs to hydrocarbonate-calcium with a noticeable presence of chlorides (Figure 1b). The recorded increased content of $\mathrm{Cl}^{-}$indicates a slight anthropogenic impact. This is confirmed by the low recreational load on the reservoir (park attendance is low).

The water composition of quarry reservoirs of urboterritories is heterogeneous (Figure 1c) and depends on the previously carried out type of developments, flowing reclamation channels, unorganized storm drains from adjacent roads. In the water of the quarry on the Kirpichnaya street in Brest and the Peat-swamp pond magnesium ions, $\mathrm{HCO}_{3}{ }^{-}$ and $\mathrm{Cl}^{-}$ions dominate. The water of the Gershonsky quarry is characterized as calciumsodium hydrogen carbonate-chloride. The high concentration of $\mathrm{Cl}^{-}$is due to the fact that the reservoir is formed as the result of the development of a clay quarry, in addition, surface stormwater flows from roads and the adjacent territory of the private sector enter the reservoirs.

The ionic composition of water of reservoirs of the fourth considered group directly depends on the type of the technogenic influence. In the Vizzhar reservoir, water is calciumsodium chloride. In the Military Lake of Malorita, magnesium chloride-sulfate water. The water in the pond Vyshulki, Brest, calcium-sodium hydrocarbonate. The increased concentrations of $\mathrm{Mg}^{2+}, \mathrm{SO}_{4}{ }^{2-}$ and $\mathrm{Cl}^{-}$ions determine the water characteristic of these reservoirs according to the ion composition and confirm the technogenic effect on them.

In the water bodies under study, $\mathrm{pH}$, dissolved oxygen, the content of calcium ions, hydrocarbonate ions, chlorides, sulphates, phosphates, meets the standards for water bodies within settlements and recreational zones. In terms of the total mineralization of water in the water bodies under study, they belong to weakly mineralized (Figure 2), which is characteristic of the region under study [3,4]. However, in the pond Mukhina Yama of 
Zhabinka and the Lower Pond of May $1^{\text {st }}$ park, Brest, the mineralization of water is increased and approaches the maximum permissible concentrations (MPC $1000 \mathrm{mg} / \mathrm{dm}^{3}$ ) for the surface waters of settlements and recreational zones. This is due to the increased content of calcium and magnesium salts in the water (Figure 1b).

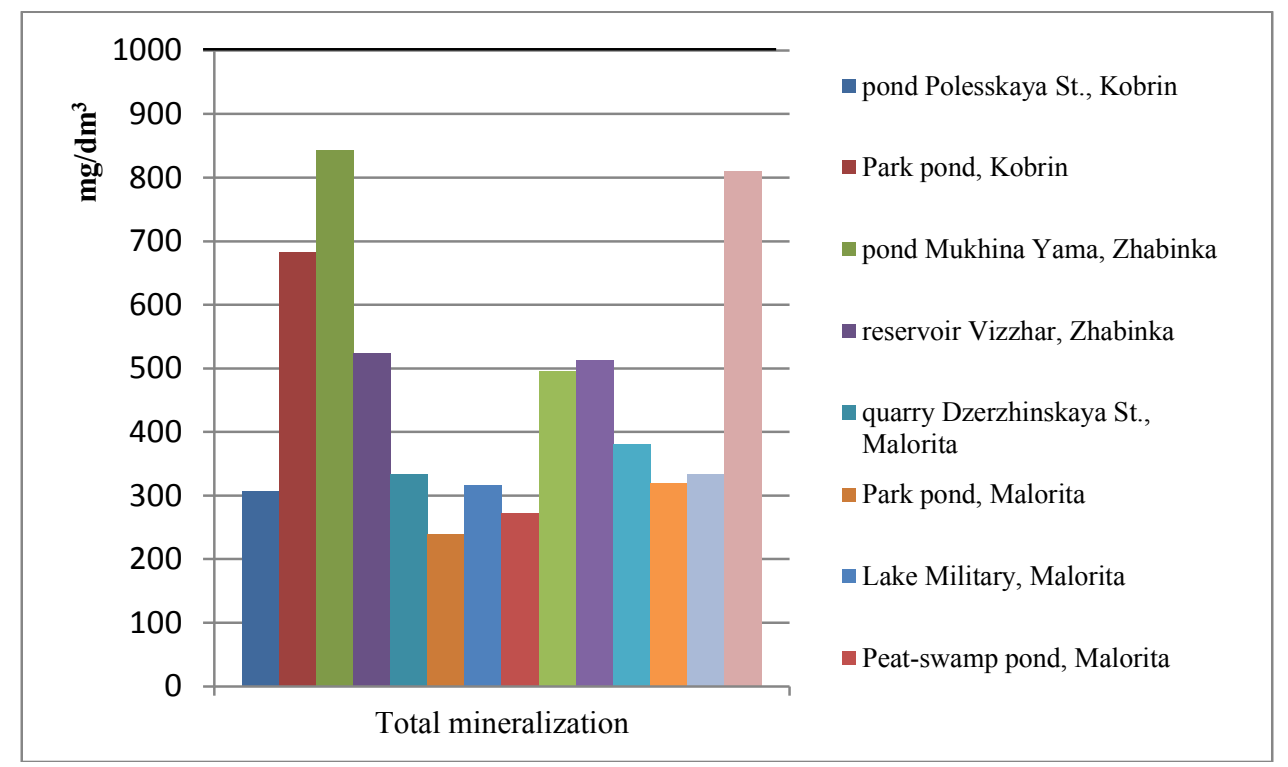

Fig. 2. Indicator of total mineralization of reservoirs of southwestern Belarus in the spring 2020.

To determine the water pollution of urban reservoirs, indicators were considered whose content exceeded the maximum permissible concentration (MPC) with the most stringent (minimum) values from the combined lists of information documents of the Republic of Belarus on the quality of surface water within settlements, recreational zones, and MPC drinking water. The characteristics of the level of contamination with substances are given by the multiplicity of the excess MPC $[22,23]$. Based on the results of the study, the level of pollution of water bodies in terms of the multiplicity of excess MPC is set as low and medium. The content of the pollutants for the spring period of 2020 in the reservoirs of the areas of private residential development by the multiplicity of MPC is shown in Figure 3.

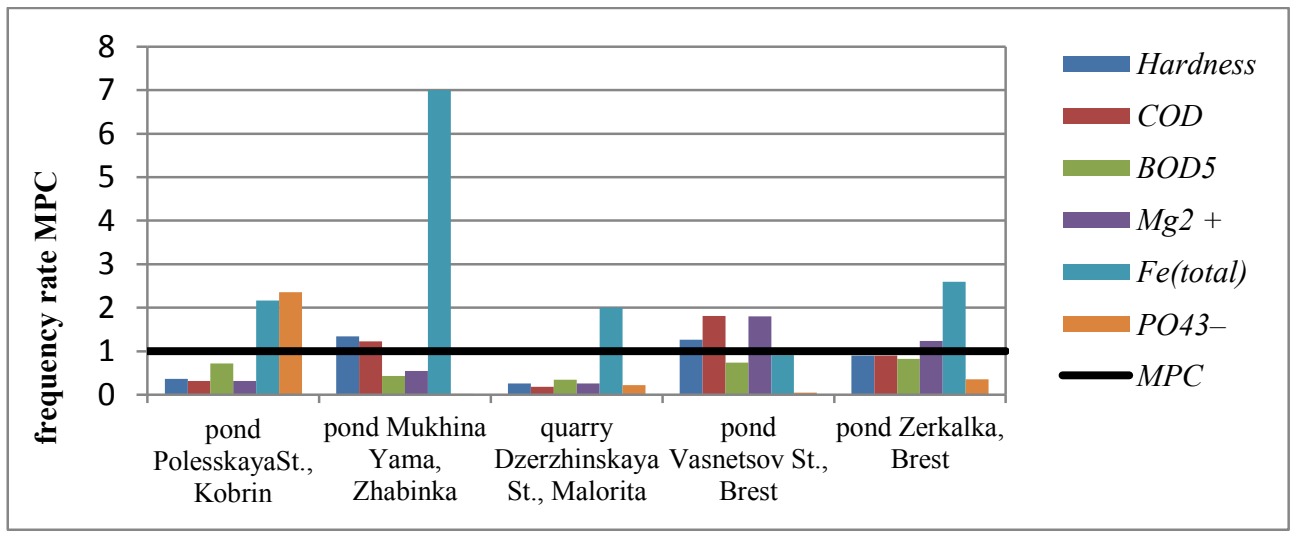

Fig. 3. The content of pollutants in the reservoirs of the private residential areas of the urboterritories of southwestern Belarus, spring 2020. 
Based on the results of the study, the increase in the level of contamination with iron and phosphates with substances was established for the pond on Polesskaya street, Kobrin, for the pond Mukhina Yama in Zhabinki - for hardness, COD and general iron. In the ponds of Brest, a similar trend is observed: increased COD, hardness, $\mathrm{Mg}^{2+}$, Fe total. In the quarry on Dzerzhinsky street the water is clean, the recorded 2 times excess of MPC Fe is generally typical for the region under study.

Water contamination by the magnitude of the MPC excess ratio was recorded by hardness, $\mathrm{Mg}^{2+}$ and iron common for most park reservoirs (Figure 4). There is a slight excess of MPC in the water of the park pond of Malorita according to $\mathrm{COD}, \mathrm{BOD}_{5}$, general iron.

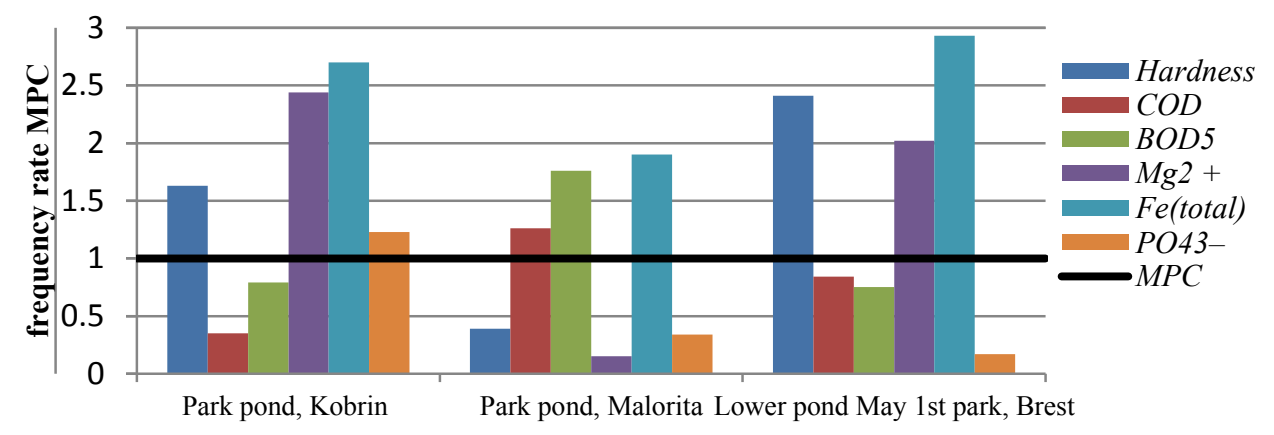

Fig. 4. The content of pollutants in the park ponds of the urboterritories of southwestern Belarus, spring 2020.

The content of pollutants for the spring period of 2020 in quarrying reservoirs of urbanized territories by multiplicity of MPC is shown in Figure 4. In all reservoirs, there is a tendency to increase the total iron content. In a quarry on Dzerzhinskaya street in Malorita, the content of substances in other indicators does not exceed the MPC, the water in the reservoir is clean. In the water of Peat-swamp, an excess of COD and $\mathrm{BOD}_{5}$ standards was found. This indicates the contamination of water with readily oxidizable organic and inorganic substances [24-26]. In the watered quarries of Brest, the water is hard, an excess of MPC of 1,1-1,5 times is observed. The water hardness in these reservoirs is directly proportional to the concentration of $\mathrm{Mg}^{2+}$ ions (Figure 5). The increase in $\mathrm{Mg}^{2+}$ concentrations is due to the abnormal discharge of surface stormwater from the adjacent area.

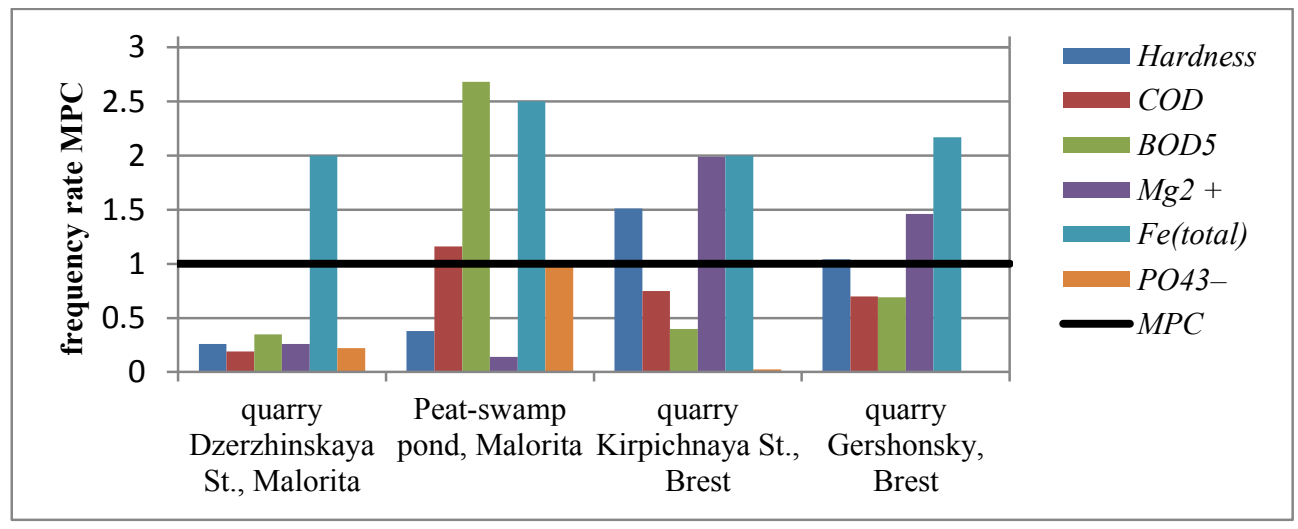

Fig. 5. The content of pollutants in the quarry reservoirs of the urboterritories of southwestern Belarus, spring 2020. 
The waters of the water bodies with the expressed anthropogenic influence are characterized by exceeding MPC in several indicators (Figure 6). As in other reservoirs, there is a tendency to increase the total iron content by 2-5,5 times.

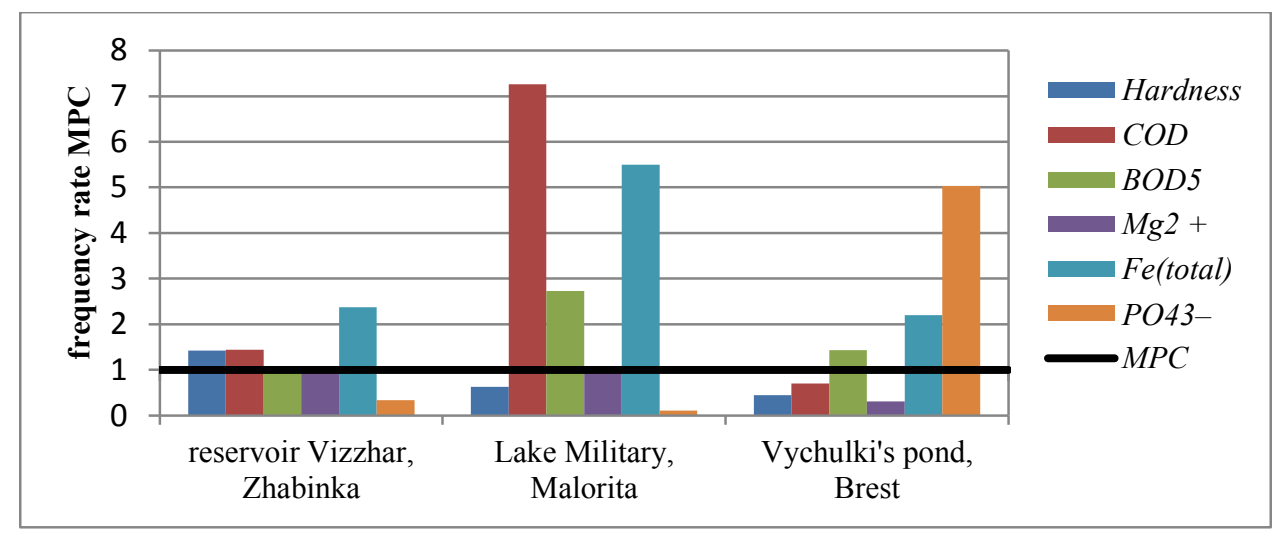

Fig. 6. The content of the pollutants in the water bodies of the urboterritories with the expressed anthropogenic influence, spring 2020.

In the reservoir of Vizzhar, Zhabinki, the multiplicity of excess MPC of pollutants is insignificant (1,1-1,5 times), but this excess is observed on 5 indicators: $\mathrm{COD}, \mathrm{BOD}_{5}$, content of ions $\mathrm{Mg}^{2+}$, hardness and general iron. This is due to the presence of under-treated industrial wastewater in the water of JSC Zhabinkovsky Sugar Plant. The water of Lake Military of Malorita is contaminated with slightly oxidizable organic substances, according to $\mathrm{BOD}_{5}$ the MPC indicator is 2,7 times exceeded, and for COD - 7,3 times. This indicates the eutrophication of this reservoir [27-29]. In the pond of Vyshulki in the town of Brest, a steady excess of MPC phosphates by 5 times was established. This pollution is due to the ingress of unorganized surface wastewater and storm water from the adjacent territory of the JSC Greenhouse Plant Berestier into the reservoir.

\section{Conclusion}

The conducted hydroecological studies have led to the following conclusions:

1. Based on the analysis of hydromorphological indicators, the typification of the urban reservoirs by water surface area was carried out. The predominance of very small and very small reservoirs of natural-anthropogenic origin in the considered urboterritory has been established. The predominance of the urbanized reservoirs of a rounded shape has been revealed. However, it has been found that the shape of the reservoir is completely dependent on the anthropogenic effects.

2. The waters of the urbanized reservoirs of southwestern Belarus are weakly mineralized, but the increased salt content has been revealed for the reservoirs of the Park Pond of Kobrin, the Mukhina Yama pond of Zhabinki and the Lower Pond of May $1^{\text {st }}$ park, Brest. These reservoirs are characterized by a high content of calcium and magnesium compounds and, as a result, increased hardness.

3 . Based on hydrochemical indicators in the spring of 2020, the level of pollution of most of the water bodies under study is low, except for the water bodies subject to technological impacts - for these water bodies the level of pollution is set as average. The level of pollution at the Vizzhar in Zhabinki depends on the discharged industrial wastewater of JSC Zhabinkovsky Sugar Plant; the level of contamination of Lake Military in Malorita depends on the discharged wastewater of the Bakery of RPO Maloritsky 
District and Maloritsky Canning and Vegetable Drying Plant; the pond Vychulki of Brest from the surface wastewater and storm water entering the reservoir of JSC Greenhouse Plant Berestier.

\section{References}

1. Vlasov, B.P. (2001). Nature-economic classification of lakes of Belarus. Selected scientific dressings of the Belarusian State University: at 7 Vol., V. 7.: 314-332 (in Russian). https://elib.bsu.by/handle/123456789/5030

2. Kirichenko, L.A. Problems of monitoring small water bodies of urbanized territories. Land reclamation and rural construction. Search for youth: Collection of scientific works of students, undergraduates, graduate students and applicants. (Belarusian State Agricultural Academy): 67-68 (2019) (in Russian).

3. Koronkevich, N.I., Barabanova, E.A., Zaitseva, I.S., Semenov, V.A., Korytny, L.M., Babkin, V.I., Dolgov, S.V., Chepalyga, A.L., Georgiadi, A.G., Shaporenko, S.I., Kichigina, N.V., Naprasnikov, A.T., Malinin, V.N., Fedorov, V.N., Shmakin, A.B., Taratunin, A.A., Borshch, S.V., Dobrovolsky, S.G., Istomina, M.N., Volchak, A.A., and other. Extreme hydrological situations. (Media-Press, Moscow (2010) (in Russian).

4. Volchak, A. A., Meshyk, A. P., Sheshka, M. M., \& Bulskaya, I. V. (2016). Floods on the Territory of Polesie. In Procedia Engineering (Vol. 162, pp. 91-97). Elsevier Ltd. https://doi.org/10.1016/j.proeng.2016.11.020

5. Volchak, A.A., Bulskaya, I.V. (2017). Water Resources of Belarus under Changing Climate Conditions: Current Status and Prognosis. Environmental Processes 4, 125-136. https://doi.org/10.1007/s40710-017-0231-1

6. Szumińska, Danuta \& Czapiewski, Sebastian \& Goszczyński, Jacek. (2020). Changes in Hydromorphological Conditions in an Endorheic Lake Influenced by Climate and Increasing Water Consumption, and Potential Effects on Water Quality. Water. 12. 1348. $10.3390 /$ w12051348.

7. Malozemova, O.V. (2012). Morphometric characteristics of lakes in various landscapes of the east of the Leningrad region. News of the Russian State Pedagogical University named after A.I. Herzen, (144), 112-121 (in Russian).

8. Gorodnichev, R.M., Levina, S.N., Ushnitskaya, L.A., Davydova, P.V., Pestryakova, L.A. (2020). Morphometric parameters of different lake types in the north of Yakutia. Advances in current natural sciences, 1: 18-25 (in Russian). http://www.naturalsciences.ru/en/article/view?id=37316

9. Ryanzhin, S.V., Myakisheva, N.V. \& Zhumangaliev, Z.M. (2015). Morphometric and hydrochemical characteristics of Kazakhstan lakes. Water Resour 42, 658-669. https://doi.org/10.1134/S0097807815050139

10. Chetverova, A., Skorospekhova, T., Morgenstern, A., Alekseeva, N. , Spiridonov, I. and Fedorova, I. (2018). Hydrological and Hydrochemical Characteristics of Lakes in the Lena River Delta (Northeast-Siberia, Russia), Polarforschung, Bremerhaven, Alfred Wegener Institute for Polar and Marine Research, 87 (2), pp. 111-124 . doi: 10.2312/polarforschung.87.2.111

11. Sanitary rules and norms 10-124 RB 99. Drinking water. Hygienic requirements for water quality of centralized drinking water supply systems. Quality control (1999) (in Russian).

12. Sanitary rules and norms 2.1.2.12-33-2005 "Hygienic requirements for the protection of surface waters from pollution," approved by Decree No. 198 of the Chief State Sanitary Doctor of the Republic of Belarus of November 28, 2005 (in Russian). 
13. TAP 17.06-17-2018 (33140) Technical code of established practice. Environmental protection and management. Hydrosphere. Comprehensive environmental risk assessment and calculation of permissible recreational loads on water bodies in recreation areas of Belarus. Ministry of Natural Resources, Minsk. p. 24 (2018) (in Russian).

14. Sanitary norms and rules "Requirements for the maintenance of surface water bodies during their recreational use"; Hygienic standard "Permissible values of water safety indicators of surface water bodies for recreational use," approved by Decree of the Ministry of Health of the Republic of Belarus dated December 5, 2016 No. 122 (in Russian).

15. Hygienic standards 2.1.5.10-21-2003 "Maximum permissible concentrations (MPC) of chemicals in the water of water bodies of drinking and cultural and domestic water use," approved by Decree of the Chief State Sanitary Doctor of the Republic of Belarus dated December 12, 2003 No. 163(in Russian).

16. Kirichenko, L.A. (2019). State of ecological status of reservoirs of the Western Bug River basin. Bulletin of the Brest State Technical University: Water construction, heat power engineering, geoecology, 2 (115): 78 - 81. (in Russian).

17. Bulskaya, Ina \& Volchek, Aliaksandr. (2014). Inorganic constituents in surface runoff from urbanised areas in winter: The case study of the city of Brest, Belarus. Oceanologia. 56. 373-383. 10.5697/oc.56-2.373.

18. Bulskaya, I., Volchek, A. (2015). Pollution of surface runoff from the territory of Brest, Belarus. Water Supply 1 April 2015, 15 (2): 256-262. https://doi.org/10.2166/ws.2014.106

19. Rashid I., Romshoo SA. (2013). Impact of anthropogenic activities on water quality of Lidder River in Kashmir Himalayas. Environ Monit Assess, 185(6):4705-4719. doi:10.1007/s10661-012-2898-0

20. Subba Rao, N., Sunitha, B., Adimalla, N. et al. (2020). Quality criteria for groundwater use from a rural part of Wanaparthy District, Telangana State, India, through ionic spatial distribution (ISD), entropy water quality index (EWQI) and principal component analysis (PCA). Environ Geochem Health, 42, 579-599. https://doi.org/10.1007/s10653-019-00393-5

21. Leslie DL, Lyons WB. (2018). Variations in Dissolved Nitrate, Chloride, and Sulfate in Precipitation, Reservoir, and Tap Waters, Columbus, Ohio. Int J Environ Res Public Health. 15(8):1752. Published 2018 Aug 15. doi:10.3390/ijerph15081752

22. Hydrochemical Institute (2002). RD 52.24.643-2002. Metodicheskiye ukazaniya. Metod kompleksnoy otsenki stepeni zagryaznennosti poverkhnostnykh vod po gidrokhimicheskim pokazatelyam [Regulatory Document RD 52.24.643-2002. Methodical guidelies. Method of comprehensive assessment of the pollution rate of surface waters using hydrochemical indicators]. Saint Petersburg: Gidrometeoizdat, 50 p. (in Russian).

23. Dvurechenskaya, S. Ya., Bulycheva, T. M. (2017). Opredeleniye kachestva vody vodokhranilishcha po integralnym pokazatelyam $\mathrm{v}$ periody raznoy vodnosti [Determination of the water quality of the reservoir by an integral indicators in different periods of water content]. Water and Ecology: Problems and Solutions, No. 1 (69), p. 44-53 (in Russian).

24. Prokop, Pawel \& Wiejaczka, Łukasz \& Syiemlieh, Hiambok \& Kozłowski, Rafał. (2019). Response of Water Chemistry to Long-Term Human Activities in the Nested Catchments System of Subtropical Northeast India. Water. 11.988. 10.3390/w11050988. 
25. Justus B, Meredith B. (2014). Water quality of potential reference lakes in the Arkansas Valley and Ouachita Mountain ecoregions, Arkansas. Environ Monit Assess. 186 (6): 3785- 3800. doi:10.1007/s10661-014-3657-1

26. Alobaidy, A., Abid, H. and Maulood, B. (2010). Application of Water Quality Index for Assessment of Dokan Lake Ecosystem, Kurdistan Region, Iraq. Journal of Water Resource and Protection, Vol. 2 (9), 792-798. doi: 10.4236/jwarp.2010.29093.

27. Collins Robert, Jenkins Alan. (1996). The impact of agricultural land use on stream chemistry in the Middle Hills of the Himalayas, Nepal. Journal of Hydrology, Vol. 185, Issues 1-4, 71-86. ISSN 0022-1694, https://doi.org/10.1016/0022-1694(95)03008-5.

28. Bhatt, M.P., Hartmann, J., \& Acevedo, M.F. (2018). Seasonal variations of biogeochemical matter export along the Langtang-Narayani river system in central Himalaya. Geochimica et Cosmochimica Acta, 238, 208-234.

29. Wang, R., Xu, T., Yu, L. et al. (2013). Effects of land use types on surface water quality across an anthropogenic disturbance gradient in the upper reach of the Hun River, Northeast China. Environ Monit Assess. 185, 4141-4151. https://doi.org/10.1007/s10661-012-2856-X 